\title{
ARTIGO
}

\section{Sociedade, Cultura e Trabalho Digno}

\author{
Society, Culture and Decent Work
}

\section{Cláudio Jannotti da Rocha'}

Lorena Vasconcelos Porto ${ }^{2}$

Anna Karoliny Alexandre Fonseca ${ }^{3}$

\begin{abstract}
RESUMO: O trabalho contemporâneo é capaz de libertar? O Direito do Trabalho consegue cumprir a sua missão teleológica? No contexto atual, quais são as condições necessárias para se assegurar o exercício concreto do direito fundamental ao trabalho digno? O presente artigo busca discutir essas e outras questões centrais ao mundo do trabalho na atualidade, utilizando a metodologia qualitativa, consubstanciada no critério dedutivo e nos instrumentos doutrinários e legais.
\end{abstract}

Palavras-chave: contemporaneidade; cultura; trabalho; dignidade.

\begin{abstract}
Is contemporary work capable of liberating? Can Labour Law fulfill its teleological mission? In the current context, what are the necessary conditions to ensure the concrete exercise of the fundamental right to decent work? This article aims to discuss these and other issues central to the world of work today, using the qualitative methodology, embodied in the deductive criterion and the doctrinal and legal instruments.
\end{abstract}

Keywords: contemporaneity; culture; work; dignity.

1 Professor Adjunto do Curso de Direito da Universidade Federal do Espírito Santo. Pós-Doutorando em Direito pela Universidade Federal da Bahia (UFBA). Doutor em Direito e Processo do Trabalho pela Pontifícia Universidade Católica de Minas Gerais (PUC MINAS). Coordenador do Grupo de Pesquisa Trabalho, Seguridade Social e Processo: diálogos e críticas (UFES-CNPq).

2 Procuradora do Trabalho. Doutora em Autonomia Individual e Autonomia Coletiva pela Universidade de Roma II. 3 Graduanda do Curso de Direito da Universidade Federal do Espírito Santo (UFES). Membro do Grupo de Pesquisa Trabalho, Seguridade Social e Processo: diálogos e críticas (UFES-CNPq). 


\section{INTRODUÇÃO}

É costumeiro, desde a infância, ouvir que estudar ratifica alguém no mundo. Muito provavelmente, o objetivo daqueles que incentivam o estudo, desde o ensino fundamental, é visar à inserção no mercado de trabalho e garantir estabilidade financeira em bons cargos. A partir disso, seria provido o sustento da família e garantida uma vida boa.

Essa tônica, por vezes indiscutível, em alguns núcleos familiares, dita determinadas condutas individuais até a fase adulta. Por esse motivo, cursos extracurriculares como língua estrangeira, informática e outros são incentivados.

Quando o mérito acadêmico não é alcançado, iniciam-se, em conjunto, as aulas particulares de matérias pouco desejáveis, sempre em busca de preencher as diretrizes exigidas pelo mercado.

A narrativa é quase sempre imutável: crianças devem estudar e tirar boas notas para que sejam financeiramente independentes no futuro. Situação muito bem demonstrada pela banda inglesa Pink Floyd no clipe da música Another Brick In The Wall.

Aqueles que atingem o socialmente esperado desempenho escolar, e se destacam com notas altas, dificilmente conseguem pensar de maneira independente ao sistema. De outro giro, os que, por vezes, não obtêm as maiores notas, mas se destacam nas artes, literatura, esportes e filosofia são os que mais comumente desenvolvem senso crítico para promover mudanças internas. Estes, por vezes, são considerados dissidentes, incapazes e indesejáveis ao mercado de trabalho. Assim, criatividade e sensibilidade perdem cada vez mais espaço para o aprendizado mecanicista e involuntário.

Nesse contexto, a grande expansão, notadamente nos últimos anos, da educação a distância se, por um lado, propicia a redução de custos em uma conjuntura de crise econômica e requer que seja alcançado um universo bem maior de indivíduos, por outro, pode comprometer os debates, as discussões, as reflexões críticas entre alunos e professores, contribuindo para o aprofundamento do controle social.

Simbolicamente, esse cenário fabrica e modula intelectualmente os indivíduos ao socialmente exigido. Isto é, há um molde cultural e comportamental no qual a equação da vida é simplificada: valores e fatores são somados e o seu produto exitoso - o sucesso financeiro - implica a felicidade sistemática. 
Huxley, em Admirável Mundo Novo, cria uma sociedade distópica na qual, desde antes do nascimento, é exercido o controle do Estado, ou seja, os bebês nascem somente por inseminação artificial - de acordo com a demanda de determinado indivíduo na sociedade. Nessa sociedade não é defeso pelo Estado o uso de "soma", uma droga que tem o objetivo único de fazer os cidadãos esquecerem momentaneamente seus infortúnios.

Fazendo-se uma analogia, a "soma" permitida pelos governos atuais e que tem o poder de distrair os indivíduos da vida árdua, uma estratégia culturalmente firmada, é o consumo. O consumo, motor do capitalismo contemporâneo, é o vício sustentado historicamente por toda uma comunidade.

Esse contexto corrobora o locus da competição intersubjetiva entre indivíduos, a qual, por meio da incessante busca de superação entre os indivíduos - seja no ambiente de trabalho com vistas a uma promoção de cargo, seja no ambiente estudantil, com o intento de se destacar academicamente -, cria um terreno fértil ao desenvolvimento de doenças psíquicas como ansiedade e depressão.

O que se percebe, no entanto, é que, da forma como é articulado e manipulado, o conhecimento acadêmico é sobreposto a todas as outras formas de saber. Essa articulação favorece que grupos específicos, selecionados pelo sistema, tenham o acesso facilitado por meio de suas condições financeiras ou seu status social.

Dessa forma, o predomínio do conhecimento academicista sobre outros, associado à irregularidade do acesso, propicia a legitimação da dominação racional-legal ${ }^{4}$ de uns sobre outros por meio da estratificação socialmente perpetrada.

Assim, a alternância de classe e uma efetiva inclusão social de grande parte da população se dão em um numerário ainda não democrático e necessário, mantendo-se o status quo dentro dessa sistematicidade.

Utilizando-se da necessidade do ser humano de se aprimorar, fomenta-se esse círculo vicioso, que nada mais faz do que manter o status quo. Assim, não deixa margem ao homem para se libertar de suas verdadeiras amarras e, pelo contrário, o aprisiona cada vez mais na posição em que se encontra e, pior, sem que ele perceba. Normalmente, o que é ensinado é o que é visto como indispensável à manutenção do sistema.

4 De acordo com Max Weber, consubstancia-se em uma dominação alicerçada pelo aparato burocrático da sociedade e tem como princípios fundamentais a hierarquia funcional, a administração baseada em documentos, a demanda pela aprendizagem profissional, a oficialização das atribuições e a exigência de rendimento máximo do profissional. (WEBER, Max. Ensaios de Sociologia. Rio de Janeiro: Guanabara, 1981). 
George Orwell, na obra 1984, desenha uma sociedade também distópica, contudo menos futurista, se comparado a Huxley. Uma das mensagens mais marcantes do livro é o slogan do Partido: "Guerra é paz; Liberdade é escravidão; Ignorância é Força".

Nessa ótica, uma característica marcante de regimes totalitários é o uso da linguagem simbólica como meio de alienação. Inserido em um campo ${ }^{5}$, característico a uma determinada cultura, o indivíduo é permeável a todo tipo de disposição estatal. Embora em contextos diversos, vê-se que a liberdade, nos dias atuais, é totalmente deturpada frente ao microcosmo social.

Paulatinamente, inseridos na cultura, com mudanças quase imperceptíveis ou, também, determinadas, há uma subversão de interesses, restando, mormente, o interesse profissional, pois é esse capaz de alcançar a estabilidade econômica. Uma garantia disso, ainda na adolescência, é quando momentos de lazer são sacrificados - incluindo aniversários e festas familiares - em favor dos estudos incessantes para o vestibular.

É uma força exógena que prevalece sobre o anseio endógeno. Como resultado disso, surgem milhares de profissionais insatisfeitos ou infelizes, que provavelmente seriam exímios em outras áreas que não aquela em que está inserido.

Estuda-se, no primeiro e no segundo grau, pensando na universidade, e quando nela se está, vislumbra-se a inserção no mercado de trabalho hostil para recém-formados. Assim, a mente humana dificilmente se alinha ao corpo físico, pois conduz, indefinidamente, conjecturas futuras. Vive-se o presente sempre pensando no (suposto e desejável) futuro. Isto é, não se vive realmente o presente. Isso adoece e retira o sentimento, o pertencimento e o reconhecimento. Aliena-se a alma, rouba-se o hoje e teme-se o amanhã. O socioeconômico domina o emocional.

Pode-se asseverar que o trabalho realizado na vida adulta corresponde ao resultado do estilo de vida, perpassando pela infância e juventude. A profissão que se exerce hoje não é fruto do desejo sublime, advindo do mais profundo sentimento; é na verdade reflexo da carga axiológica que foi constituída a partir do contexto no qual o indivíduo foi inserido por seus familiares.

5 Pierre Bourdieu define campo como um microcosmo social dotado de certa autonomia, com leis e regras específicas. É um lugar de luta entre os agentes que o integram e que buscam manter ou alcançar determinadas posições. Nesse viés, o lugar que os agentes ocupam nessa estrutura é que indica suas tomadas de posição. (TEIXEIRA PEREIRA, Elaine Aparecida. O conceito de campo de Pierre Bourdieu: possibilidade de análise para pesquisas em história da educação brasileira. Revista Linhas. Florianópolis, v. 16, n. 32, p. 337-356, set./dez., 2015. Disponível em: http://www.revistas.udesc.br/index.php/linhas/article/view/1984723816322015337/ pdf 97. Acesso em: 12 nov. 2019. 
Paulatinamente, o motor que movimenta os sonhos é sobressaltado ao inconsciente, onde ficam subjugados à maquinação socialmente exigida das ações. É a cobrança social (família, escola, vizinhos, colegas e namorados) que vagarosamente vai dominando a psique. Assim, o que é culturalmente reconhecido, advindo do que é imposto pela sociedade, pelo mercado consumerista e pelo sistema, domina suntuosamente o cérebro e o âmago do ser humano.

Quanto à cultura, seu conteúdo e sua imponência, ensina Mário Vargas Llosa em $A$ Civilização do Espetáculo:

Tal como a elite, a classe social é uma realidade que deve ser mantida, pois nela se recruta e forma a casta ou o grupo que garante a alta cultura, elite que em caso algum deve identificar-se totalmente com a classe privilegiada ou aristocrática da qual seus membros procedem em maior número. Cada classe tem a cultura que produz e que lhe convém, e, embora entre elas naturalmente haja coexistência, também há diferenças marcantes relacionadas com a condição econômica de cada uma ${ }^{6}$.

Nesse ínterim, os elementos que formam a cultura moldam todas as etapas de desenvolvimento vital do ser humano, não sendo diferente, portanto, com o trabalho. A sociedade se estrutura a partir da cultura como elemento aglutinador e determina os valores socialmente aceitos. Dessa forma, trabalhos mecânicos que visem ao operariado ou profissões estimadas ganham relevo sobre as atividades laborais menos queridas socialmente.

Inquestionavelmente, se uma sociedade culturalmente prioriza o bem-estar das pessoas, a dignidade da pessoa humana, a inclusão social dos desfavorecidos e das minorias, todos os tipos de trabalho devem ser valorizados e normatizados como um direito fundamental acessível que permita uma efetiva melhoria da condição socioeconômica dos trabalhadores, concedendo-lhes um patamar mínimo civilizatório. Esse é um mandamento da própria Constituição Federal de 1988 que, ao consagrar a dignidade como fundamento, traz o ser humano como finalidade precípua da atividade estatal e centro convergente de direitos ${ }^{7}$.

Assim como a cultura é uma forma de dominação, o trabalho também o é, afinal este é fruto daquela. Logo, se a cultura domina o inconsciente, o trabalho domina

6 LLOSA, Mario Vargas. A civilização do espetáculo. Rio de Janeiro: Objetiva, 2013. p. 12-13.

7 Vide: DELGADO, Gabriela Neves. Estado Democrático de Direito e Direito Fundamental ao Trabalho Digno. REIS, Daniela Muradas; MELLO, Roberta Dantas de; COURA, Solange Barbosa de Castro (coord.). Trabalho e justiça social: um tributo a Mauricio Godinho. São Paulo: LTr, 2013. 
fisicamente. Metaforicamente, pode-se dizer que a sociedade é um carro em movimento. O motor é a cultura e o trabalho é o lugar no qual se almeja chegar.

Para continuar inserido nessa jornada é necessário trabalhar. É por meio do trabalho que se perpassa a sinergia que conduz a mola propulsora da sociedade: a necessidade humana.

É justamente nela que o trabalhador se coloca à disposição, sujeitando-se a condições que lhe são impostas - por vezes até mesmo sub-humanas e indignas - para em troca ter o que comer e sobreviver, nos remetendo às lições de Primo Levi:

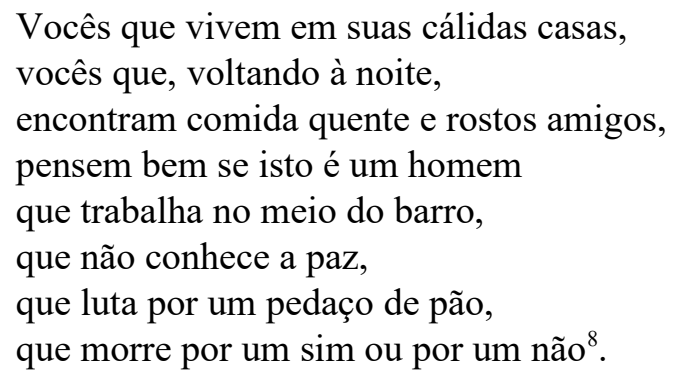

Outrossim, a necessidade guia ao consumo. Outrora a cultura nos obrigava a trabalhar e, a partir do nosso salário, estabelecer o nosso consumo; hodiernamente, a lógica é invertida: primeiro se consome e, partindo do consumo, se trabalha o necessário para pagar as contas, situação intitulada por Zygmunt Bauman como "vida para consumo".

De tempos antigos, a inclusão social se dá pelo consumo proporcionado pelo trabalho, o que transforma as pessoas em reféns das mercadorias que consomem. $\mathrm{O}$ ser humano deixa de ser um fim em si mesmo, para ser meio. A sociedade caminha cada vez mais para uma individualização, abrindo mão da coletivização.

A sociedade passa a ser líquida e fluida, os valores e as relações interpessoais diluem-se facilmente, o trabalho entra em queda livre. Ao invés de unir as pessoas e trazer solidariedade, torna-as competidores e as segrega, perpetuando a estratificação das classes sociais. Assim, imperam o mal-estar da pós-modernidade e a banalização do mal.

É nesse cenário que surgem as novas modalidades de trabalho consubstanciadas na cultura do descarte do ser humano e da valorização do consumo desenfreado, que torna o homem não mais como detentor de direitos e de afeto, mas como um ser assentimental.

8 LEVI, Primo. É isto um homem? Rio de Janeiro: Rocco, 2013. p. 45. 
Em pleno século XXI, ainda se discutem os atributos que permitem ao trabalho fincar os alicerces da vida digna, livre e inclusiva do sujeito na esfera socioeconômica, dando a impressão de inaceitável retrocesso, enquanto há questões prementes a serem discutidas para se avançar de fase.

Restam, portanto, os questionamentos: o trabalho contemporâneo é capaz de libertar? O Direito do Trabalho consegue cumprir a sua perspectiva teleológica? No contexto atual, quais são as condições necessárias para se assegurar o exercício concreto do direito fundamental ao trabalho digno? A metodologia será qualitativa, consubstanciada no critério dedutivo e nos instrumentos doutrinários e legais.

\section{O SISTEMA, A SOCIEDADE, A CULTURA, O TRABALHO: SUAS (INTER)FACES, (IN)VARIÁVEIS (IM)PERCEPTÍVEIS}

\section{Do comunismo primitivo ao capitalismo}

Alguns dizem que trabalho é castigo, outros dizem que trabalho é libertação, que dignifica o ser humano. Fato é que o trabalho, uma racionalidade humana, transformação da natureza de maneira direcionada pelo homem, dificilmente será consenso, pois envolve uma série de variáveis e é resultado de um processo sociocultural, de determinado tempo e espaço.

O trabalho acompanha o ser humano desde a pré-história e, ao longo do tempo, se transmuda e se transforma, encontrando-se em uma constante metamorfose, variando conforme a época em que é realizado.

Na mesma medida em que a sociedade muda, a cultura se modifica, o trabalho se altera e o trabalhador se adequa. Toda essa sistematicidade se transforma, mas o trabalho permanece sendo a principal atividade humana: um dispêndio de energia direcionado e racionalizado que, via de regra, oferta o sustento do ser humano.

Indubitavelmente essa transição no mundo do trabalho é advinda da mudança da cultura implementada naquela época, fruto da modificação da sociedade. $\mathrm{O}$ trino composto por sociedade, cultura e trabalho se retroalimenta.

Durante a pré-história, quando o homem era nômade e vivia da caça e da coleta, lutando contra animais em busca da sua sobrevivência, ele era livre, pois os utensílios de trabalho a todos pertenciam e, assim, os frutos do labor pertenciam a quem o realizava ou eram repartidos por todos. Desse modo, a única relação de dominação vale dizer, simbólica - era em favor do líder das tribos. 
$\mathrm{Na}$ Antiguidade Clássica, o regime escravagista era a forma com que as cidadesestados gregas puniam seus prisioneiros de guerra - principalmente advindos da Ásia Menor e da Trácia -, forçando-os a realizar as mais diversas atividades, dentre elas as policiais e artesanais.

Com a mundialização da escravidão, a relação de dominação é severa, tanto entre particulares, quanto entre países imperialistas e suas colônias. O trabalho, portanto, completamente inserido nessa realidade, transforma o ser humano em meio para a realização de algo (com fim econômico específico).

Na Idade Média, no período nomeado feudalismo, a sociedade era, sobretudo, agrícola, e vivia nos campos cultivados por meio da servidão, de onde eram retirados os recursos necessários à sobrevivência.

Com a mudança do modo de produção escravagista para o feudalista, o trabalhador deixa de ser escravo para ser servo. Enquanto o escravo era patrimônio dos senhores, podendo ser vendido, trocado ou alugado, o servo à terra pertencia e a ela era vinculado.

\section{Do capitalismo}

Posteriormente, na Idade Moderna, surgiu o constitucionalismo ensejador do Estado de Direito, época em que é efetivado o sistema capitalista (teoria da acumulação). É justamente nesse momento histórico que emerge a figura do empregado. Assim, se antes a sociedade e a cultura impunham que os escravos e os servos fossem dominados pela força e pelo medo, a partir de então passou a direcionar a dominação por meio da lei. É novamente a mudança socioeconômica que ensejou um direcionamento cultural que impôs as mudanças no mundo do trabalho.

A ideia do constitucionalismo tem sua origem na Inglaterra, nos Estados Unidos e na França, sendo fruto das Revoluções Burguesas. A partir desse momento histórico, o mundo ocidental foi alterado profundamente, passando a sociedade a ser regulamentada por um direito positivado em um documento escrito denominado Constituição.

O Estado de Direito é caracterizado pelo seguinte tripé: divisão de poderes, supremacia das leis e limitação do poder. Rompia-se o absolutismo e surgia o governo das leis. Inicialmente, o constitucionalismo se operacionalizou por meio do Estado Liberal de Direito, quando surgiram os direitos civis, notadamente a liberdade, a igualdade, a participação política e a propriedade, aliados ao absenteísmo estatal. 
A fome, a miséria, as péssimas condições de vida e o surgimento da máquina a vapor, provocaram um êxodo rural em razão do qual algumas cidades da Inglaterra foram infladas com o contingente recebido.

Esses centros, até então pouco habitados, passaram a ser o cenário ideal para o estabelecimento das indústrias e das fábricas, afinal reuniam em seu bojo os elementos que fomentaram a exploração da mão de obra: I) um contingente absurdo de pessoas carentes de qualquer ajuda e que clamavam por empregos para não morrerem de fome e de frio; II) o surgimento da máquina a vapor; III) a ascensão de uma nova classe social que ganhava cada vez mais força e alcançava o poder por meio das Revoluções Burguesas e; IV) a liberdade e a igualdade estabelecidas na lei, que legitimaram toda a exploração sofrida pela classe trabalhadora e as péssimas condições de trabalho.

Mão de obra abundante, barata, disponível, todos sendo iguais e livres perante a lei e a máquina para otimizar a produção formaram o contexto perfeito para a "sinfonia de Beethoven".

As Corporações de Artes e Ofícios, caracterizadas pela produção artesanal e manufatureira, foram extintas dando espaço para o industrial. Surgia, então, a primeira Revolução Industrial, na segunda metade do século XVIII, na Inglaterra, caracterizada pela criação da máquina a vapor, invento que, de forma inquestionável, mudou todo o panorama do mundo do trabalho.

Dividiam-se, doravante, a produção e o trabalho, que passou a ser em massa e fragmentada. A partir de então cada trabalhador era alocado a uma máquina com a qual, mecanicamente, se relacionava. Logo, se as cidades mudaram, a cultura mudou e o trabalho também. As cidades, que eram pequenas, tornaram-se grandes, a produção em baixa escala passou para grande volume e o trabalho artesanal tornou-se industrial.

É novamente a sociedade alterando a cultura que, por seu turno, impõe novos modelos paradigmáticos no mundo do trabalho, pois o êxodo rural inverteu toda a lógica que prevalecia na sociedade e no trabalho: se antes ela se encontrava no campo, diversificada, até mesmo isolada, e as pessoas em contato com a natureza e de certa maneira com qualidade de vida, a partir de então passou a fixar-se na cidade, de maneira concentrada, aglomerada e em contato com prédios, construções, em péssimas condições de moradia, de saneamento básico e vivendo de maneira corrida. 
Essa mudança de epicentro cultural ensejou reflexos no mundo do trabalho: a produção, que era quase uma obra de arte, em que o trabalhador transformava a matéria-prima no produto final, participando de todo o processo de produção, fazendo seu labor com uma relativa tranquilidade, tornou-se um processo mecânico e sistematizado, no qual o trabalhador labora de maneira industrial, fabricando tão somente uma parte do produto que ele nem sabe que produz, em um ritmo acelerado e sofrendo uma heterodireção patronal incisiva e impetuosa.

As mesmas mudanças ocorridas na sociedade direcionaram as modificações no mundo do trabalho. Desse modo, se no campo morava-se com relativa qualidade e passou-se a residir na cidade em péssimas condições de saneamento básico, no trabalho, o labor manufatureiro cedeu lugar para o trabalho mecanizado, em condições sub-humanas, que geraram um número alarmante de acidentes de trabalho que mataram milhares de trabalhadores.

No decorrer do tempo, surgiram as indústrias de algodão, linho, tratamento de lã, preparação da seda, a produção de ferro, a construção de ferrovias e de estradas e a construção do barco a vapor (que permitiu inclusive as descobertas de novos territórios - continentes).

A criação da máquina e sua utilização na indústria trouxeram consigo um pano de fundo pouco dito e analisado, que alteraria profundamente o mundo laboral: o trabalho deixava de ser uma atividade exclusivamente humana para ser também da sua criação. Doravante, o homem dividia espaço com aquilo que criava: a máquina. Era o trabalho vivo dividindo espaço com o trabalho morto. Iniciava-se uma nova era que não teria mais data para se findar.

Há que se mencionar, também, as circunstâncias às quais homens, mulheres e crianças estavam subordinados nas fábricas. A mão de obra feminina e infantil era preferível à masculina, uma vez que representava menor custo e menor resistência, e as crianças tinham facilidade de lidar com as máquinas.

As mulheres eram colocadas em trabalhos específicos e meticulosos, sendo seus direitos recusados, inclusive a licença maternidade. Observa-se que mulheres grávidas - independentemente da fase gestacional - eram admitidas para a realização de trabalhos.

As crianças tinham a função de adentrar nas máquinas para consertá-las, em razão de seu pequeno porte, sendo tais reparos necessários para que as máquinas continuassem 
a funcionar e a trazer lucros crescentes. Vale dizer que, em virtude da massa muscular e da estatura, homens adultos não eram ideais para realizar diversos desses reparos.

Os salários eram baixíssimos e as condições de trabalho eram péssimas, com jornadas extenuantes, sem qualquer tipo de segurança, e em contato com agentes nocivos os mais diversos. Esse cenário ensejou o número absurdo de acidentes, que matou e mutilou milhares de trabalhadores.

No desenrolar da modernidade, as ambições econômicas e o senso de superioridade moral humano ampliaram-se exponencialmente, gerando cenários de exploração humana que culminaram em milhares de mortes, consubstanciadas no binômio legal: liberdade e igualdade.

A ascensão da segunda Revolução Industrial, a partir da segunda metade do século XIX, com expansão para o restante da Europa e dos Estados Unidos, possibilitou que a máquina a vapor desse lugar à máquina movida à eletricidade e ao petróleo, otimizando-se profusamente a exploração do labor e aumentando-se, em uma relação de causa e efeito, a produção e o lucro, com a introdução nas indústrias dos sistemas de produção taylorista e fordista.

Os sistemas taylorista e fordista potencializaram ainda mais o modo de produção, otimizando consideravelmente a velocidade de entrega do produto ao consumidor, exigindo do trabalhador uma disciplina quase que perfeita e totalmente mecanicista; o trabalho vivo perde espaço de forma exponencial para o trabalho morto. $\mathrm{O}$ objetivo principal era produzir o maior número possível de mercadorias, reproduzindo-se o que já havia sido planejado pelo empregador.

Novas descobertas (expansão das ferrovias e a produção do aço) fomentam mudanças sociais e o capitalismo ganha força e dinamismo. Dessa forma, os países protagonistas da industrialização tornam-se nações desenvolvidas e passam a dominar e controlar outros países que, mediante o processo de colonialismo e imperialismo, tornam-se periféricos e submissos.

Com a evolução das embarcações, o homem pôde alcançar terras outrora distantes, em velocidade otimizada, permanecendo ainda mais tempo no mar, levando os seus interesses para lugares até então impensáveis e inimagináveis.

Em busca de novas maneiras de baratear os custos de produção, com benefícios fiscais e leis flexíveis, as metrópoles procuram colônias por meio das navegações. 
A partilha dos continentes africano e asiático, no século XIX, ensejou bastante descontentamento entre os países europeus. A Alemanha e a Itália foram excluídas do processo colonial, ao passo que a França e a Inglaterra estavam explorando diversos novos territórios, riquíssimos em matérias-primas e com enorme mercado consumidor.

É por desdobramentos desse contexto (associados a outros fatores) que ocorre a Primeira Guerra Mundial (1914-1918), conflito que envolveu as grandes potências de todo o mundo, que se organizaram em duas alianças opostas: a Tríplice Aliança (Alemanha, Itália e Império Austro-Húngaro) e a Tríplice Entente (França, Inglaterra e Rússia).

Em 11 de novembro de 1918, a Alemanha assina o Acordo da Paz, dando-se por rendida, sendo que, em janeiro de 1919, foi instalada a Conferência da Paz, no Palácio de Versalhes. Decidiu-se pela necessidade da fixação de princípios fundamentais de proteção ao trabalho humano e da criação de um organismo internacional com atribuições de promover a internacionalização das normas sociais trabalhistas e controlar sua aplicação.

Assim, em 1919, a Organização Internacional do Trabalho (OIT) é constituída como parte da Liga das Nações (arts. $6^{\circ}, 387$ e 426 do Tratado). Foi reconhecido que a sustentabilidade da paz mundial e do ser humano deveria ocorrer por meio do primado do trabalho.

Pode-se dizer que o objetivo nuclear da OIT é fomentar a reconstrução do mundo a partir da perspectiva inclusiva das pessoas pelo primado do trabalho, constituindo um piso mínimo trabalhista para o ser humano que labora.

A inclusão social do ser humano, advinda do seu labor, permite que todos ganhem: o trabalhador alcança a sua subsistência e tem sua dignidade reconhecida, a empresa vende os seus produtos, a sociedade tem o bem-estar social e o Estado arrecada tributos.

As normas internacionais se tornam obrigatórias para os países membros da Organização Internacional do Trabalho (OIT) e representam o piso mínimo que tais países devem observar, evitando-se em escala global o dumping econômico e social e, portanto, a concorrência desleal.

A par disso, houve a promulgação das primeiras Constituições Sociais do mundo: a Mexicana, em 1917, e a Alemã de 1919. 
É nesse bojo que, no final do século XIX e início do século XX, o Direito do Trabalho se afirma como ramo jurídico autônomo, dotado de regras e princípios próprios, tendo como núcleo duro a relação de emprego, à qual é destinado todo um arcabouço normativo que visa a assegurar um patamar mínimo civilizatório, para resguardar a dignidade, a vida e a integridade física e psíquica do trabalhador. É, justamente por isso, que as normas trabalhistas, principalmente as de saúde e segurança, são indisponíveis, imperativas e cogentes, de ordem pública.

O Direito do Trabalho brasileiro traz em seu alicerce o "patamar mínimo civilizatório", formado pelo seguinte trino: 1-) direitos constitucionais; 2-) tratados e convenções internacionais vigorantes no Brasil; 3-) normas legais infraconstitucionais que asseguram patamares de cidadania (por exemplo, identificação profissional, combate à discriminação, saúde e segurança no trabalho, pisos salariais). A partir desse complexo normativo, alcança-se o "direito fundamental ao trabalho digno", defendido por Gabriela Neves Delgado.

No Brasil, a Constituição de 1934, inspirada na Constituição de Weimar, traz normas de Direito do Trabalho, tratando da dignidade da pessoa humana, constitucionalizando questões sociais e econômicas, elevando ao plano constitucional direitos trabalhistas como a jornada semanal de trabalho máxima, a autonomia e pluralidade sindical, o salário mínimo, férias, o repouso semanal remunerado, a indenização por despedida imotivada, a isonomia salarial, as restrições ao trabalho do menor, o repouso semanal remunerado, as férias anuais remuneradas, o acidente de trabalho e o reconhecimento das convenções coletivas.

A Constituição de 1934 estabeleceu, ainda, que todos que exercem trabalho honesto possuem o direito de alcançar a própria subsistência e de sua família, bem como criou a Justiça do Trabalho, de cunho administrativo, vinculada ao Poder Executivo, que somente em 1941 foi instalada e passou a integrar o Poder Judiciário em 1946.

Portanto, o surgimento do Direito do Trabalho representa um avanço, pois, com a normatização da relação de emprego, o trabalhador, a partir de seu labor, passa a ter acesso ao patamar mínimo civilizatório, uma gama de direitos que lhe dá acesso ao direito fundamental ao trabalho digno, capaz de lhe ofertar uma efetiva inclusão social, melhoria da condição socioeconômica e reconhecimento da sua dignidade, possuindo assim um caráter libertário.

Muito embora no plano constitucional a Carta Magna de 1934 tenha sido um marco civilizatório, no plano infraconstitucional já existiam diversas leis esparsas que tratavam de questões sociais, como é o caso do Decreto $\mathrm{n}^{\circ} 1637$, de 1907 , que 
facultava a criação de sindicatos profíssionais e sociedades cooperativas; Lei $\mathrm{n}^{\circ}$ 3.724, de 1919, que instituiu o seguro de acidente de trabalho; Lei $\mathrm{n}^{\circ} 4.682$, de 1923, que criou as Caixas de Aposentadorias e Pensões para ferroviários; Lei $\mathrm{n}^{\circ} 4.982$, de 1925, que estabeleceu férias de 15 dias anuais aos empregados de estabelecimentos comerciais, bancários e industriais; e o Código de Menores (Decreto $\mathrm{n}^{\mathrm{o}}$ 17.934, de 1927), que estabelece a idade mínima de 12 anos para o trabalho e a proibição do trabalho noturno e do trabalho em minas para os menores.

Após a Segunda Guerra Mundial (1939-1945), desponta a terceira Revolução Industrial, técnico-científico-informacional, que faz emergir o sistema toyotista de produção, caracterizado pela informatização. Criado por Eiji Toyoda, no Japão, tem como característica principal a flexibilização da produção e se difundiu pelo mundo a partir de 1970, após a sua aplicação pela fábrica da Toyota, empresa japonesa que despontou como uma das maiores do mundo na fabricação de veículos automotivos.

Pode-se dizer que consistiu em uma oposição à premissa básica do sistema anterior. No fordismo, prevalecia a máxima acumulação dos estoques. No toyotismo, prevalece a adequação da estocagem dos produtos conforme a demanda, produzindose tão somente o necessário.

Assim, quando a procura por uma determinada mercadoria é grande, a produção aumenta, mas quando essa procura é menor, a produção diminui proporcionalmente. Se antes a produção ditava o ritmo do consumo, a partir de então o consumo que dá o ritmo da produção, invertendo-se toda a lógica do mundo do trabalho. Com isso, emprega-se somente o necessário para produzir.

O surgimento do toyotismo, mais uma vez, reflete a mudança da sociedade, que impõe uma nova modalidade cultural, a qual altera o mundo do trabalho. O Japão é um exemplo, pois, em virtude das condições geográficas, das transformações decorrentes da Segunda Guerra Mundial e do seu reduzido mercado consumidor, não conseguiu adequar-se ao modelo fordista de produção em massa.

Eiji Toyoda visitou na década de 1950 algumas fábricas norte-americanas para conhecer melhor os processos produtivos pautados pelo sistema fordista. Durante essa viagem percebeu que eram empresas gigantescas e que detinham grandes espaços para a estocagem de produtos industrializados, contexto bem diferente do que tinha em mãos no Japão.

Ao fazer as suas constatações, Toyoda não tardou em perceber que o seu país, o Japão, vivendo um complicado período pós-guerra, não conseguiria se adequar àquele 
modelo industrial. A partir de então, começou a idealizar um sistema em que a produção ocorresse de forma mais flexibilizada.

Decorrido pouco tempo após a implementação do sistema toyotista de produção, eis que a sociedade novamente altera a sua forma de agir e, consequentemente, sua cultura e o mundo do trabalho. Logo, se no início do século $\mathrm{XX}$ o verbo que determinava a sociedade era ter; no final do século XX passou para possuir e agora, e no início do século XXI é usar.

Pouco importa quem é o proprietário ou o possuidor do bem, mas sim o uso dele. A partir do uso, o bem ou a pessoa ganha importância e valor. Para que se tenha o maior número de usuários, deve-se compartilhar o bem, multiplicando-se, assim, o seu uso e aumentando o seu valor.

A partir do uso, o compartilhamento ganha potencial, maior importância e valor. Desse modo, compartilha-se o carro, o apartamento (ele na integralidade ou até mesmo parte dele), a bicicleta, o patinete, o escritório, as informações de dados pessoais, os livros, o ônibus, o helicóptero, a roupa e até mesmo o trabalhador. $\mathrm{O}$ valor do bem e das pessoas é de acordo com o número de usuários interessados (demanda).

Quanto maior a procura pelo uso, o preço sobe. A todo o momento a sociedade compartilha-se e, consequentemente, fragmenta-se veladamente. A partir de uma falsa aparência de evolução, tem-se um retrocesso, porquanto o verdadeiro pano de fundo é que tudo aquilo que não está sendo usado não tem importância. É o uso que dá as cartas do jogo, ele que dita o preço de tudo.

E para que o compartilhamento seja potencializado, surge a necessidade de novas tecnologias acessíveis ao maior número de pessoas, mormente os celulares, computadores e tablets. Por meio de aplicativos instalados nesses aparelhos, o ser humano tem o mundo na palma de sua mão; com um simples toque na tela, consegue acessar sites, contratar pessoas, serviços e consumir produtos.

Esse binômio uso/compartilhamento enseja um efeito até então pouco mencionado na doutrina brasileira: a diversidade. A partir do momento que, para se ter acesso a um bem, você não precisa mais tê-lo ou possuí-lo, mas tão somente usá-lo no exato tempo que ele lhe é útil, emerge o compartilhamento do bem e, consequentemente, misturam-se os produtos e os serviços, fomentando o cliente a usar o maior número de bens possíveis ao mesmo tempo. 
Nesse aspecto, o consumidor é livre para escolher o que, como, quando, qual e onde vai usar o produto. Assim, misturam-se produtos e serviços, idênticos ou parecidos, para que a pessoa tenha uma liberdade plena de optar pelo produto e serviço que desejar ao seu bel prazer. Por isso e para isso, são criados os mais diversos aplicativos para intermediar e facilitar o acesso a esses produtos e serviços, tais como Uber, Amazon, Buser, Loggi, Rappi, Shipp, Booking, Airbnb, 99pop, Diaríssima, Getninjas, Uber Eats, Colmeia, IFood, Picpay, Grin e Yellow. É neste novo universo que surgem as startups.

A trilogia que direciona a sociedade e a cultura contemporânea é o uso, compartilhamento e diversidade, o que chegou ao mundo do trabalho. A palavra que consubstancia essa correlação é a liberdade, afinal todos querem ser livres, inclusive para escolher tudo, principalmente, o que ser, fazer, consumir e aonde ir.

É neste âmbito que, no início do século XXI, surge a $4^{\mathrm{a}}$ Revolução Industrial, pautada pela cyberização, alterando ontologicamente o trabalho, o que ensejou uma verdadeira miscigenação laboral. Esta, no Brasil, foi institucionalizada pela reforma trabalhista, que inseriu no ordenamento jurídico brasileiro, entre outras figuras contratuais precárias, o intermitente, fruto das mudanças sociais e culturais acima demonstradas.

O trabalhador intermitente só é contratado no dia e na hora em que é demandado, posto que sua mão de obra é compartilhada por diversos tomadores ao mesmo tempo, realizando os mais diversos tipos de serviços. $\mathrm{O}$ intermitente é literalmente a descartabilidade e a mercantilização do ser humano no mundo do trabalho.

Por outro lado, as empresas 4.0 a todo o momento divulgam o uso dos seus produtos em redes sociais, organizam-se de maneira compartilhada e diversificam seu quadro de funcionários em vários tipos de trabalhadores, tornando a empresa um local de miscigenação laboral, passando a aceitar, recentemente, pagamentos em moedas digitais. Neste cenário constitui-se a gig economy.

O trabalho cyberizado corresponde a um gênero, composto pela junção da utilização de aplicativos, de plataformas digitais, da robotização, da inteligência artificial, da implementação de chips nos trabalhadores, da fragilização do sigilo de dados, das criptomoedas e da discriminação genética.

O pano de fundo de toda essa revolução - que a cada dia mais ganha força - é a automação parcial ou total da indústria e da fábrica, hipótese por muitos intitulada 
fábrica inteligente. Neste novo modelo empresarial, o trabalho morto adquire maior importância, fazendo com que o trabalho vivo perca espaço e magnitude.

Até então, quem dava as ordens aos empregados era uma pessoa física; agora é uma máquina ou até mesmo o próprio cliente. A subordinação se opera através de aplicativos e de plataformas digitais, cujos proprietários são os empregadores do momento. O tomador do serviço pode estar próximo ou distante do empregado, até mesmo em outro país ou continente, pois quem vai dizer o que e para quem deve ser feito é uma plataforma ou aplicativo por meio de algoritmos.

Seguindo as mudanças socioculturais, no Brasil, emergiram novas formas empregatícias além do intermitente, como o teletrabalhador, a ampliação da terceirização e do trabalho temporário, o hiperssuficiente, o trabalhador autônomo contínuo e exclusivo, entre outras figuras precárias.

Pouco a pouco, o empregado cede lugar ao colaborador que vai sendo substituído pelo empreendedor. Criam-se várias opções para legitimar um argumento falacioso: o trabalhador tem a liberdade para escolher a forma que deseja trabalhar, como se de fato fosse livre para optar e não estivesse vinculado ao desejo do empregador, aos seus desígnios e à necessidade de sobrevivência.

Cria-se uma cadeia empregatícia precária, que almeja reduzir os custos barateando a mão de obra do trabalhador. Destaca-se que essas formas estratificadas segregam a sociedade a partir do trabalho realizado pelo ser humano, porquanto violam o patamar mínimo civilizatório, bem como prejudicam a atuação sindical e a circulação de renda, além de ensejar uma abrupta queda na venda/consumo de bens e de mercadorias e também da arrecadação tributária do Estado.

Em síntese, todos saem prejudicados com a implementação dessas novas modalidades de trabalho, de modo que o passado ainda está presente, tendo em vista que a $4^{\text {a }}$ Revolução Industrial é parte do presente, mas não o domina em sua integralidade. Logo, se antes o Direito do Trabalho era corroído, agora ele se desnatura.

Efeito irradiador de todos esses fatores é a enorme proliferação da denominada "economia de bico". Esta compreende duas formas principais de trabalho: o "crowdwork", que abrange a realização de tarefas a partir de plataformas online, e o trabalho "on-demand", que envolve a execução de labores tradicionais, como o transporte, a limpeza, ou de escritório, demandados por meio de aplicativos gerenciados por empresas, sendo a mais conhecida a Uber, razão pela qual se utiliza também a expressão "uberização" das relações de trabalho. 
Nessas formas de trabalho, como o intermitente, o homem é tratado como descartável, se tornando refém de suas necessidades e das demandas e condições que lhe são impostas, que geralmente são de extrema exploração e aceitas diante da indispensabilidade em receber, afinal ele não sabe quando será demandado novamente. A alteridade - que sempre foi e é exclusiva do empregador - vai, ainda que de maneira quase imperceptível, sendo transferida para o empregado, como em uma ampulheta na qual a areia passa vagarosamente ao outro lado.

\section{O LABOR CONTEMPORÂNEO LIBERTA?}

A nova lógica empresarial da indústria 4.0, pautada pela miscigenação laboral, consubstanciada na tônica da liberdade, insere em seu método de produção as mais diversas formas de relação de trabalho (o tradicional, o intermitente, o pejotizado, o terceirizado, o teletrabalhador, por tempo parcial, o hipersuficiente, o autônomo).

Concomitantemente, além de causar enorme prejuízo ao trabalhador quando não contratado como empregado (tendo violados diversos direitos e garantias fundamentais), também prejudica o Estado. Isso acontece, pois diversas vezes o salário recebido não é suficiente para cobrir todas as despesas, subsistência familiar e não são recolhidos os tributos devidos ${ }^{9}$.

Esses são caros ao Estado, pois, por meio dos impostos, as políticas públicas são feitas e a máquina governamental é alimentada. Não obstante, o meio ambiente do trabalho também é prejudicado com a precarização. Trata-se de um dano social, vez que prejudica a sociedade por inteiro.

Através e em nome da lei as novas modalidades empregatícias são utilizadas para otimizar a produção e aumentar o lucro, em detrimento dos direitos mínimos que todo e qualquer empregado é titular, núcleo do direito fundamental ao trabalho digno.

Essa poluição socioambiental ocasionada pela miscigenação empregatícia acarreta uma verdadeira insegurança no empregado: o medo de não ser demandado quando

9 Um estudo da Receita Federal demonstra que um dos principais motivos para a "pejotização" dos trabalhadores é a redução do ônus tributário na contratação de serviços. A empresa tomadora acaba se desincumbindo de $31 \%$ dos encargos trabalhistas, tais como contribuição previdenciária patronal (20\%), encargos do Sistema S e do RAT (3\%), depósito para o FGTS (8\%), além dos demais direitos trabalhistas que devem ser assegurados, como décimo terceiro salário, férias, horas extras, vale-transporte, vale-alimentação, benefícios previstos nas normas coletivas etc. Ademais, na faixa de renda equivalente a $\mathrm{R} \$ 30.000$ mensais, o peso dos tributos federais corresponde a $23,6 \%$ da renda bruta auferida pela pessoa física, na condição de empregado regularmente contratado. Caso esse profissional constitua uma pessoa jurídica ("pejotização") e estabeleça um contrato de prestação de serviços com a empresa tomadora, a incidência tributária é reduzida para 17,34\% (redução de 6,26\%). (BRASIL. Receita Federal. O Fenômeno da "Pejotização" e a Motivação Tributária. Brasília, 2016).

Laborare. Ano III, Número 4, Jan-Jun/2020, pp. 32-54. ISSN 2595-847X. https://trabalhodigno.org/laborare DOI: https://doi.org/10.33637/2595-847x.2020-47 
mais precisar. Sendo assim, se antes o empregado pedia para não ser explorado, hoje ele roga: explore-me, pois preciso trabalhar.

A competição (já citada neste trabalho) entre os próprios colegas de profissão prejudica o pertencimento e o reconhecimento do trabalhador no local em que ele convive e permanece a grande parte do seu dia. A partir do momento em que se encontram no mesmo ambiente, pessoas que estão inseridas dentro da mesma ótica e perspectiva (embora não realizem expressamente a mesma atividade) estão dominadas pela lógica empresarial.

Desse modo, se antigamente a produção era just in time, agora o trabalhador também o é, tendo em vista que ele sempre deve estar pronto para trabalhar, na hora em que é demandado, quando o consumidor aciona o aplicativo/plataforma e a empresa faz a intermediação e o controle do trabalho realizado.

O que interliga a demanda do consumidor, a intermediação/controle da empresa e o trabalhador é a disponibilidade imediata desse último em trabalhar: ele deve estar sempre à disposição durante todo o dia. Em nome do empreendedorismo, cria-se uma empresa de um homem só, para somente ele trabalhar em nome dela, não podendo se fazer substituir por mais ninguém, até porque ele é o único trabalhador da empresa e, por isso, deve estar sempre pronto para quando for demandado, sob pena de perder a oportunidade ou até mesmo o emprego.

É óbvio, claro como a luz do sol, que estamos diante de uma fraude trabalhista, pois esta empresa é falsa ou este autônomo também é falso, usados para mascarar o que todos nós já sabemos: trata-se de um empregado.

A insegurança do trabalhador é tamanha a ponto de ele se expor a jornadas de trabalho extenuantes, sem as mínimas condições de segurança e saúde, sem a utilização de equipamentos de proteção, por salários-dia aquém do mínimo, sem descanso semanal, intervalos, nem férias, décimo terceiro, e completamente afastado do âmago previdenciário.

Nessa seara, o número de óbitos por ano, no Brasil, é compreensível, sendo que aproximadamente 10 pessoas por dia morrem trabalhando no país e a cada 48 segundos acontece um acidente de trabalho ${ }^{10}$.

No Brasil, quarta posição no ranking mundial de acidentes de trabalho, a Previdência Social registra por ano cerca de 700 mil casos e, segundo dados do Observatório

10 Disponível em: https://areasst.com/acidentes-de-trabalho-no-brasil/. Acesso em: 07 jul. 2019. 
Digital de Segurança e Saúde do Trabalho, o país chega a contabilizar uma morte por acidente em serviço a cada três horas e quarenta minutos. É uma carnificina laboral, nada menos do que isso ${ }^{11}$.

O medo e a incerteza do amanhã fazem com que o empregado se exponha ao máximo hoje e, com isso, sua vida fica vulnerável, seja fisicamente ou psicologicamente. O número de doenças advindas do labor é um fator cada vez mais presente no mundo do trabalho e na vida do trabalhador, como a depressão, a neurose, a psicose, a síndrome de burnout, a ansiedade, o estresse e a bipolaridade.

Somando-se a esse cenário os números alarmantes de 13,4 milhões de desempregados e 28,3 milhões de subutilizados ${ }^{12}$, alcança-se a rotatividade que torna o trabalhador descartável, afinal, quando ele não puder ou não quiser (já que ele é "livre"), alguém sempre vai querer. E, assim, acirra-se ainda mais a competição laboral. Tem-se um exército de necessitados.

Portanto, a busca pelo melhor emprego atinge diretamente o lado competitivo dos empregados, estraçalhando o sentimento de solidariedade entre eles, prejudicando o convívio social e seu lado psíquico. E, com isso, o meio ambiente deixa de ser saudável e sadio. O pertencimento e o reconhecimento no local do trabalho evaporam e o ser humano torna-se descartável no processo produtivo, tendo importância somente quando demandado e necessário.

Esse é o cenário sombrio e catastrófico fomentado pela $4^{\mathrm{a}}$ Revolução Industrial, digno de um filme de terror. O pesadelo reside na hipótese de não ser utilizado e assim nada receber, não tendo o que comer, onde morar, o que vestir, ou ainda ter acesso aos estudos, ao lazer e demais condições básicas para que se possa ter uma vida digna a partir do trabalho que realiza e assim exercer o seu direito basilar de cidadania. Muitos doutrinadores indagam: haverá trabalho no futuro? Fato é que o trabalho não é mais uma atividade exclusivamente humana, vejamos a Sophia.

É como se diariamente o trabalhador caminhasse no sentido de um precipício e qualquer esmola que lhe aparece no caminho ele aceita para postergar a tragédia: não ter trabalho.

Sob uma falsa aparência de que caminhamos para um mundo melhor pautado pela liberdade, o que se percebe é um verdadeiro retrocesso social, afinal ao contrário de o trabalho ser um

11 Disponível em: http://atarde.uol.com.br/empregos/noticias/2058823-brasil-ocupa-quarta-posicao-noranking-de- acidentes-de-trabalho. Acesso em: 20 jul. 2019.

12 Disponível em: https://g1.globo.com/economia/noticia/2019/04/30/desemprego-sobe-para-127percent-emmarco-dizibge.ghtml. Acesso em: 20 jul. 2019.

Laborare. Ano III, Número 4, Jan-Jun/2020, pp. 32-54. ISSN 2595-847X. https://trabalhodigno.org/laborare DOI: https://doi.org/10.33637/2595-847x.2020-47 
instrumento emancipador, caminha no sentido de ser um instrumento de dominação e de repressão, podendo inclusive ser considerado uma pena e não uma liberdade.

Assim, se antes o escravo era propriedade do senhor, o servo preso à terra, na qual trabalhava, o empregado vinculado à empresa, o trabalhador atual é meramente usado e dependente do consumo de outra pessoa, perfazendo-se uma falsa liberdade dominada pelos aplicativos instalados nos celulares, computadores e tablets. Estes controlam mais do que seu corpo físico, mas também a sua alma e mente.

\section{CONCLUSÃO}

Ante o exposto, se é impossível precisar a história, assim também o é o mundo do trabalho quanto à relação triádica entre a sociedade, a cultura e o ser humano. Da forma como o trabalho interfere na vida do ser humano e na sociedade, também sofre interferência do sujeito que o realiza e da sociedade em que ele é realizado.

Fato é que essa tríade que se retroalimenta dia após dia, hora após hora, minuto após minuto, é imprecisa e inexata, ao passo que a sociedade interfere na cultura, e esta no trabalho, determinando seu modus operandi.

Portanto, analisar o "universo" do trabalho -, que emerge das mais profundas e complexas atividades humanas e sociais, e interfere diretamente em diversas áreas do conhecimento como economia, direito, sociologia e história -, significa incorrer na imprecisão e em desencontros temporais.

Nesse sentido, o autor deste artigo, em uma tentativa de elucidar para o leitor um contexto alarmante, arrisca o aprofundamento na história da própria humanidade, fazendo uma narrativa secular até alcançar o presente momento histórico.

Analisar se o trabalho contemporâneo traz libertação ou dominação é uma tarefa demasiado difícil e que não possui uma resposta exata, visto que ela é fruto de uma série de variáveis, principalmente quanto ao tempo e ao espaço em que ele é analisado. Afinal, a forma com que o trabalho é valorizado em uma cultura e normatizado em um determinado país vai interferir na conclusão.

Como visto ao longo deste artigo, a história do trabalho é permeada por fluxos e refluxos que acompanham o ser humano desde a pré-história. Um movimento pendular, porquanto em determinados momentos ocorreram avanços e melhoramentos e em outros recuos e desvalorização do trabalho, fazendo com que o trilhar seja alinear e incerto. 
Até o século XX, o trabalho também era sinônimo de castigo, pena. Quando o Direito do Trabalho surge, ele passa a ser valorizado e consegue, por meio da relação de emprego, alcançar um caráter libertário, ofertando ao empregado o patamar mínimo civilizatório, que alberga melhorias da condição socioeconômica, dá início à inclusão social e ao reconhecimento da sua dignidade, através do direito fundamental ao trabalho digno ${ }^{13}$.

No século XXI, essa contextualização vem sendo desnaturada, posto que as novas formas de trabalho estão ganhando espaço, fazendo com que a relação de emprego divida espaço com outras modalidades de trabalho que violam o patamar mínimo civilizatório.

Dentro do contexto acima exposto, pode-se asseverar que, nos trilhos que o mundo do trabalho caminha na contemporaneidade, o labor vai no sentido contrário da libertação, estando o trabalhador com cada vez menos direitos, menor proteção social, previdenciária e assistencial, trabalhando mais e em condições mais precárias e perigosas, sendo que os números de acidentes de trabalho e de miserabilidade só aumentam no Brasil.

As novas formas de contratação, implementadas no ordenamento jurídico brasileiro, só fazem legitimar a estratificação laboral e a segregação social a partir do trabalho. Sob a tônica da liberdade, cria-se a falsa esperança nas pessoas de que novos postos de emprego serão criados e de que o consumo vai aumentar. Logo, se todos nós somos livres, podemos escolher como queremos trabalhar. Mas, existe liberdade sem opção e sem igualdade? Uma pessoa com uma única alternativa de trabalho é livre para escolher como deseja trabalhar? Uma pessoa necessitando de dinheiro para comer, morar, vestir e suprir suas necessidades básicas pode de fato negociar ou aceita o que lhe é oferecido? Assim, o próprio Direito do Trabalho vai deixando de exercer sua função teleológica e perde força, sangra vagarosamente.

Difícil concluir que o trabalho liberta, sendo que várias novas modalidades do mundo do trabalho, inclusive empregatícias, destinam aos trabalhadores direitos aquém daqueles que lhes são devidos, violando o direito fundamental ao trabalho digno.

A precarização da mão de obra não gera mais empregos e tampouco retira um país de uma crise econômica, até mesmo porque estes nunca foram e nunca serão objetivos

13 DELGADO, Gabriela Neves. Estado Democrático de Direito e Direito Fundamental ao Trabalho Digno. REIS, Daniela Muradas; MELLO, Roberta Dantas de; COURA, Solange Barbosa de Castro (coord.). Trabalho e justiça social: um tributo a Mauricio Godinho. São Paulo: LTr, 2013. p. 254. 
do Direito do Trabalho. Pelo contrário, a retirada de direitos trabalhistas só aprofunda a crise econômica e a miséria que assolam um país, isso a História ensina.

Sendo assim, se a sociedade influencia na cultura de uma nação e esta diretamente interfere em como o trabalho será normatizado e valorizado, estamos no exato momento de refletirmos qual é o país que queremos ter e deixar de legado para os nossos filhos, netos, sobrinhos e amigos, porquanto a resposta encontra-se em cada pequeno gesto que praticamos todos os dias, nos pensamentos que nos permeiam a todo instante que estamos acordados: a empatia.

Uma sociedade que não valoriza o trabalho consequentemente desvaloriza o ser humano e prejudica a sua inclusão social e a melhoria da sua condição socioeconômica, bem como a distribuição de renda e a arrecadação tributária do país.

\section{REFERÊNCIAS}

BRASIL. Receita Federal. O Fenômeno da "Pejotização" e a Motivação Tributária. Brasília: 2016.

DELGADO, Gabriela Neves. Estado Democrático de Direito e Direito Fundamental ao Trabalho Digno. REIS, Daniela Muradas; MELLO, Roberta Dantas de; COURA, Solange Barbosa de Castro (coord.).Trabalho e justiça social: um tributo a Mauricio Godinho. São Paulo: LTr, 2013.

HUXLEY, Aldous. Admirável Mundo Novo. 22. ed. São Paulo: Globo, 2014.

LLOSA, Mario Vargas. A civilização do espetáculo. Rio de Janeiro: Objetiva, 2013.

ORWELL, George. 1984. São Paulo: Companhia das Letras, 2009.

TEIXEIRA PEREIRA, Elaine Aparecida. O conceito de campo de Pierre Bourdieu: possibilidade de análise para pesquisas em história da educação brasileira. Revista Linhas. Florianópolis, v. 16, n. 32, p. 337-356, set./dez. 2015. Disponível em: http://www.revistas.udesc.br/index.php/linhas/article/view/1984723816322015337/ pdf 97. Acesso em: 12 nov. 2019.

WEBER, Max. Ensaios de Sociologia. Rio de Janeiro: Guanabara, 1981.

Recebido: 02/04/2020

Revisado: $08 / 04 / 2020$

Aprovado: 08/06/2020 